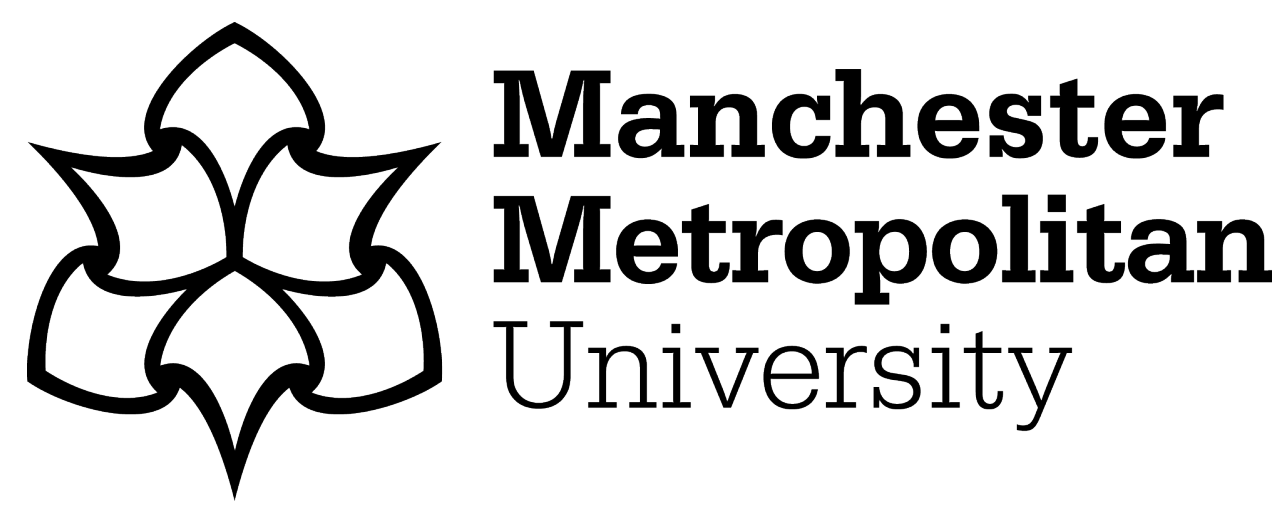

Purcell, W, Potgieter, H, Nete, M and Mnculwane, H (2018) Possible methodology for niobium, tantalum and scandium separation in ferrocolumbite. Minerals Engineering, 119. pp. 57-66. ISSN 0892-6875

Downloaded from: https://e-space.mmu.ac.uk/620401/

Publisher: Elsevier

DOI: https://doi.org/10.1016/j.mineng.2018.01.031

Usage rights: Creative Commons: Attribution-Noncommercial-No Derivative Works 4.0

Please cite the published version 


\title{
Possible methodology for niobium, tantalum and scandium separation in ferrocolumbite
}

\author{
W. Purcell ${ }^{1,2}$, H. Potgieter ${ }^{2}$, M. Nete $^{1}$ and H.Mnculwane ${ }^{1}$ \\ ${ }^{1}$ Department of Chemistry, University of the Free State, Bloemfontein, South Africa \\ ${ }^{2}$ School of Chemical and Metallurgical Engineering, University of the Witwatersrand, Johannesburg, \\ South Africa
}

\begin{abstract}
Ferrocolumbite is a well-known source of $\mathrm{Ta}, \mathrm{Nb}$ and $\mathrm{Sc}$. However, separation of these elements from such ores/process tailings, as well from each other is problematic, typically involves numerous separation steps and very corrosive and hazardous chemicals. An investigation was therefore launched to evaluate alternative separation options. As part of this endeavour it was necessary to investigate accurate quantification methods to be able to trace the elements during any proposed process.

Ferrocolumbite was successfully dissolved with $\mathrm{NH}_{4} \mathrm{~F} \cdot \mathrm{HF}\left(1: 10\right.$ sample to flux ratio at $200{ }^{\circ} \mathrm{C}$ for $60 \mathrm{~min}$ ), which yielded solutions containing 91\% Ta, $96 \% \mathrm{Nb}$ and $99 \% \mathrm{Sc}$ recoveries while satisfactory LODs $(0.07768,0.01045$ and 0.001085 respectively) were also obtained. Inclusion of a magnetic separation step (only $31 \%$ Fe in magnetic portion) to simplify the down-stream beneficiation processes did not contribute to the successful removal of Fe/Ti. Methyl isobutyl ketone (MIBK) successfully extracted the Ta in the ore $(94 \%)$ into the organic layer and left $\mathrm{Nb}$ $(88 \%)$ and $\mathrm{Sc}(99 \%)$ in the aqueous layer at $\left[\mathrm{H}_{2} \mathrm{SO}_{4}\right]<8 \mathrm{M}$. At higher acid levels $\left(\left[\mathrm{H}_{2} \mathrm{SO}_{4}\right]>\right.$ $10 \mathrm{M}$ ) the Sc present in the non-magnetic portion of the ore migrated in significant amounts and quantities $(95 \%)$ to the organic layer. Thus a possible process for the separation of the three elements from one another was created. Octan-1-ol yielded similar results to MIBK while methyl isoamyl ketone (MIAK) successfully removed Ta from the aqueous layer (87\%), but left the two other elements in the aqueous layer, even at $\left.16 \mathrm{M}^{2} \mathrm{H}_{2} \mathrm{SO}_{4}\right]$. A process flow sheet for the possible separation of $\mathrm{Nb}$, Ta and $\mathrm{Sc}$ from ferrocolumbite and mine tailings is proposed.
\end{abstract}




\section{Introduction}

Columbite-tantalite (coltan) refers to a solid solution series, which is formed between two different minerals, namely columbite and tantalite with columbite the niobium-rich group member and tantalite the tantalum-rich member (Beurlen et al., 2008). The international Mineralogical Association (IMA) discredited the general reference to columbite as mineral and replaced it with the more specific designations of ferrocolumbite (Columbite-(Fe)), which is rich in $\mathrm{Fe}$ and manganocolumbite (Columbite-(Mn), which is rich in $\mathrm{Mn}$ (Burke, 2008). Ferrocolumbite is the most common columbite specimen, the manganocolumbite less common while the $\mathrm{Mg}$ rich columbite, magnesiocolumbite (columbite- $(\mathrm{Mg})$ ) is the least common. In general, despite being discredited, the name columbite is still used without further designations.

The columbite found in Brazil is normally mined for its rich niobium content $\left(31-79 \% \mathrm{Nb}_{2} \mathrm{O}_{5}\right)$ (Pohl, 2011) and not necessarily for its smaller amounts of tantalum. The chemical characterization of the these minerals also indicate the presence of moderate quantities of iron and titanium, but also small quantities of scandium $(0.135 \%)$ and only one other "adopted" rare earth element, yttrium $(0.17 \%)$. The chemical characterization of the discarded mine tailings after the initial processing of the columbite ore at these mines or processing plants indicate the presence of large amounts of iron, moderate amounts of tantalum and niobium and smaller amounts of scandium $(0.996 \%)$ and yttrium $(0.38 \%)$.

The tantalite found in most African countries are normally tantalum rich and niobium poor and are often referred to as "blood or conflict minerals" due to the fact that finances obtained from the selling of these minerals are used to buy weapons and ammunition (Hayes and Burge, 2003). These armed and criminal elements then commit serious human rights violations, which include the mistreatment of the miners and other civilians, the use of child labor, committing widespread sexual violence as well as indiscriminate executions. International efforts such as the "DoddFrank Act" (Section 1502 of the US law) require that companies using gold, tin, tungsten and tantalum in the manufacturing of their products need to make efforts to determine if those materials came from the DRC or an adjacent country and to carry out a "due diligence" review of their supply chain (bag-and-tag) to control and legalize the tantalum market and to prevent the funding of armed or criminal groups in eastern DRC (Wolfe, 2015; Lee, 2011).

The main elements in the columbite-tantalite series, namely tantalum and niobium, are extremely important in modern day technology such as the use of Ta in cell phones, laptops and iPads while $\mathrm{Nb}$ is used as superconductors and in the manufacturing of super alloys in the construction industry (Eckert and Hermann, 1996; Ruiz et al, 2002) and as implants in medical industry (Matsuno et al, 2001). The presence of Sc as impurity in the Brazilian columbite is very interesting. Sc is not a scarce element in the earth's crust (42 most abundant element in earth's crust), but it has a low affinity for other minerals and is therefore seldom found in high grade, high volume deposits, which is commercially viable for production (Kemp and Wolf, 2006). 
Even at elevated concentration in minerals it's processing is difficult. It is commonly found in association with tungsten and tin in minerals such as wolframite, thortveitite, monazites and some granitic pegmatites (Krebs, 2006). Current estimates indicate the global market volume for $\mathrm{Sc}$ is between 10 and 15 tons per annum (U.S. Geological Survey, 2015). At these low levels of production, it is not surprising that the development of new products containing the metal is almost non-existent, although the metal has enormous potential to be used in high-tech applications due its unique properties. Added to aluminum, it produces a new alloy, which is heat-tolerant, corrosion-resistant, strong, and has excellent weldable properties, which is in high demand in the aircraft and automobile industry (Krebs, 2006). It is also used in the production of high-intensity lamps due to its unique optical properties and in the manufacturing of solid oxide fuel cells due to its exceptional heat resistance and electrical properties (U.S. Geological Survey, 2015).

Recently we completed a comprehensive and fundamental investigation on the dissolution and subsequent hydrometallurgical separation of $\mathrm{Ta}$ and $\mathrm{Nb}$ in different tantalite samples from different locations in Africa (Nete et al, 2012; Nete et al, 2013; Nete et al, 2014). Results from these studies indicated that methyl isoamyl ketone (MIAK) was very successful as solvent extractant to remove Ta from the rest of the elements in an $8 \mathrm{M} \mathrm{H}_{2} \mathrm{SO}_{4}$ solution with almost no $\mathrm{Nb}$ contamination. The $\mathrm{Nb}$ was successfully separated from the rest of the elemental impurities present in the mineral ores using a Dowex Marathon wba anion exchange resin.

A number of objectives were targeted in this study. The first was to accurately quantify the three elements of interest ( $\mathrm{Ta}, \mathrm{Nb}$ and $\mathrm{Sc}$ ) in natural columbite as well as in mine tailings, secondly to determine whether the dissolution and separation process mentioned above is also viable for columbite beneficiation and thirdly to determine the efficiency of the extraction process at higher acidity levels. The study also included the tracing of the three elements during each of the hydrometallurgical process steps to determine a possible extraction and isolation process for Sc from these kinds of minerals and waste material.

\section{Experimental}

\section{$2.1 \quad$ Equipment and materials}

Adjustable-volume Gilson Pipetman $(100 \mu \mathrm{L}-1000 \mu \mathrm{L})$ and Brand Transferpettes $(1 \mathrm{~mL}-10$ $\mathrm{mL}$ ) micro-pipettes were used for the accurate measuring and transfers of solutions. The glassware (beakers and volumetric flasks) used for all the elemental analysis was of Schott Duran, grade (A) type. The magnetic susceptibility of the samples was determined with a Sherwood Scientific magnetic susceptibility balance (MSB) at $25{ }^{\circ} \mathrm{C}$. A Shimadzu ICPS-7510 ICP-OES sequential plasma spectrometer was used for the qualitative and quantitative analyses of the ferrocolumbite and mine tailing samples. The operating conditions reported in Table 1 were maintained for all the analyses. 
Table 1: Operating conditions ICP-OES

\begin{tabular}{|l|l|}
\hline Parameter & Condition \\
\hline RF power & $1.2 \mathrm{~kW}$ \\
\hline Coolant gas flow & $14.0 \mathrm{~L} / \mathrm{min}$ \\
\hline Plasma gas flow & $1.2 \mathrm{~L} / \mathrm{min}$ \\
\hline Carrier gas flow & $0.7 \mathrm{~L} / \mathrm{min}$ \\
\hline Sample uptake method & Peristaltic pump \\
\hline Spray chamber & Glass cyclonic \\
\hline Type of nebuliser & Concentric \\
\hline
\end{tabular}

Ultra-pure water $(0.02$ to $0.00 \mu \mathrm{S} / \mathrm{cm})$ obtained via reverse osmosis was used for all the analytical solution preparations. All chemicals, reagents and samples (with their known purity) were used without further purification. $\mathrm{HCl}(32 \%), \mathrm{HNO}_{3}(65 \%), \mathrm{H}_{2} \mathrm{SO}_{4}(95-99 \%)$, MIAK ( $\geq$ $98 \%), \mathrm{H}_{2} \mathrm{SO}_{4}(95-97 \%)$, ammonium bifluoride $\left(\mathrm{NH}_{4} \mathrm{~F} \cdot \mathrm{HF}\right)$ and the ICP standards containing $1000 \mathrm{mg} / \mathrm{L} \mathrm{Nb}, \mathrm{Ti}, \mathrm{Sn}, \mathrm{W}, \mathrm{Si}, \mathrm{Ta}, \mathrm{Y}$ and $\mathrm{Sc}$ as well as a multi-element standard (32 elements) containing $1000 \mathrm{mg} / \mathrm{L}$ each of $\mathrm{Mn}, \mathrm{Al}, \mathrm{Fe}$ and other more common elements were bought from Merck. Th and U standards (1000 mg/L) were bought from De Bruyn Spectroscopic and the ICP standard solution containing $100 \mathrm{mg} / \mathrm{L} \mathrm{Sc}$ was bought from Spectrascan. The ICP standard solution containing $100 \mathrm{mg} / \mathrm{L} \mathrm{Zr}$ was purchased from Sigma-Aldrich. 1-octanol (99.5\%) was purchased from Associated Chemical Enterprises while the methyl isobutyl ketone (MIBK) (99 \%) was sourced from Saarchem. The two different mineral samples, namely the columbite sample and $\mathrm{Ta} / \mathrm{Nb}$ residue/tailing sample, labelled as Sample A and Sample B respectively (see Figure 1), originating from Brazil, were supplied by the London and Scandinavian metallurgical Co. The analytical results reported in this paper represent the average of three replicate analyses while the standard deviations are reported in such a way that it reflect the uncertainty in the calculated results (last digit of a result).

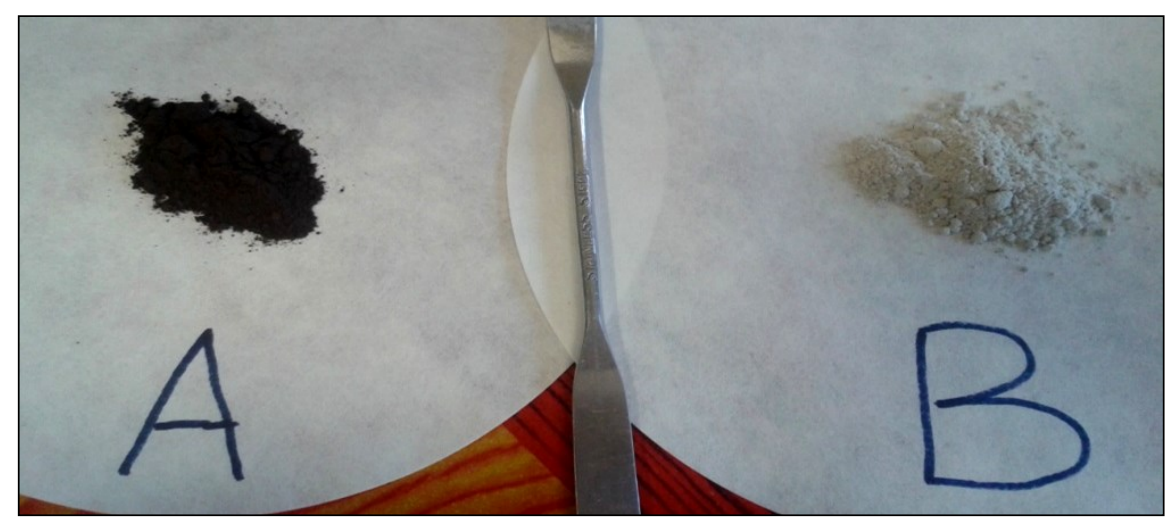

Figure 1: Columbite sample (A) and residue (B) 


\subsection{Preparation of standard solutions}

All glassware used in this study was soaked in $55 \% \mathrm{HNO}_{3}$ for about 24 hours and then rinsed 2 3 times with ultra-pure water and dried prior to use. A set of calibration standards for ICP-OES analysis was prepared by dilution of the appropriate volumes of the primary ICP standards with water in $100.0 \mathrm{~mL}$ volumetric flasks to make $0.5,1.0,3.0,5.0$ and $10.0 \mathrm{mg} / \mathrm{L}$ concentrations. The acidity of the solutions was adjusted by addition of $10 \mathrm{~mL} 95-97 \% \mathrm{H}_{2} \mathrm{SO}_{4}$ before they were filled to the mark with ultra-pure water. Blank solution preparations were similar to the calibration solutions and were used for background corrections. All prepared standard solutions were homogenized and left to stand for 5 hours before use. Quantitative analyses were performed using the ICP-OES at the selected wavelengths. Wavelength selection was based on sensitivity of the analytical line and the lack of interference by other elements in solution. Ta, $\mathrm{Nb}$ and Sc were analysed at 228.916, 309.418 and $361.384 \mathrm{~nm}$ respectively. The limit of detection (LOD) was determined using an average of the triplicate measurements of the standard solutions' intensities and ten replicate measurements of the blank solution.

\subsection{Optimizing the experimental conditions using Sample A}

\subsubsection{Dissolution of Sample A with $\mathrm{NH}_{4} \mathrm{~F} \cdot \mathrm{HF}$ fusion}

Approximately $0.05 \mathrm{~g}$ of Sample A was weighed (accurately to $0.1 \mathrm{mg}$ ) in a platinum crucible and thoroughly mixed with approximately $0.5 \mathrm{~g}$ of $\mathrm{NH}_{4} \mathrm{~F} \cdot \mathrm{HF}$ flux (1:10 sample to flux ratio). The mixture was fused at $200{ }^{\circ} \mathrm{C}$ for $30 \mathrm{~min}$ in a high temperature oven and a white amorphous solid melt was obtained. The melt was dissolved in ultra-pure water and the solution was magnetically stirred for $5 \mathrm{~min}$. Some of the solid sample remained in the solution. The residue was then filtered and the filtrate was quantitatively transferred into $100.0 \mathrm{~mL}$ volumetric flasks and filled to the mark with ultra-pure water. A $10.0 \mathrm{~mL}$ solution was pipetted into a $100.0 \mathrm{~mL}$ volumetric flask and $10 \mathrm{~mL} 95-97 \% \mathrm{H}_{2} \mathrm{SO}_{4}$ was added. The solution was left to cool down and filled to the mark with ultra-pure water for quantitative analysis using ICP-OES. The results are reported in Table 2 as the equivalent oxides of the most stable oxidation state of the elements for comparison with previously reported values. 
Table 2: Ammonium bifluoride fusion of Sample $A$ at different times and different sample: $\mathrm{NH}_{4} \mathrm{~F} \cdot \mathrm{HF}$ ratios at $200{ }^{\circ} \mathrm{C}$

\begin{tabular}{|c|c|c|c|c|c|}
\hline \multirow[b]{2}{*}{ Element } & \multirow{2}{*}{$\begin{array}{c}\text { Expected } \\
\% *\end{array}$} & \multicolumn{4}{|c|}{ Experimental \% } \\
\hline & & $\begin{array}{l}\text { 1:10 ratio and } 30 \\
\text { min }\end{array}$ & $\begin{array}{c}\text { 1:10 ratio and } 60 \\
\text { min }\end{array}$ & $\begin{array}{l}\text { 1:10 ratio and } 90 \\
\text { min }\end{array}$ & $\begin{array}{l}\text { 1:20 ratio and } 30 \\
\text { min }\end{array}$ \\
\hline $\mathrm{Nb}_{2} \mathrm{O}_{5}$ & 43.74 & 36.24 & 42.12 & 45.32 & 39.85 \\
\hline $\mathrm{Fe}_{2} \mathrm{O}_{3}$ & 29.49 & 26.12 & 29.23 & 29.51 & 26.98 \\
\hline $\mathrm{TiO}_{2}$ & 10.63 & 9.63 & 10.45 & 10.36 & 10.31 \\
\hline $\mathrm{Al}_{2} \mathrm{O}_{3}$ & 0.89 & 5.09 & - & - & - \\
\hline $\mathrm{Mn}_{3} \mathrm{O}_{4}$ & 2.10 & 1.14 & 1.66 & 1.69 & 1.19 \\
\hline $\mathrm{SnO}_{2}$ & 1.42 & 3.94 & 4.29 & 4.86 & 4.19 \\
\hline $\mathrm{U}_{3} \mathrm{O}_{8}$ & $<0.05$ & 0.00 & 0.00 & 0.01 & 0.00 \\
\hline $\mathrm{ThO}_{2}$ & $<0.055$ & 0.00 & 0.01 & 0.01 & 0.00 \\
\hline $\mathrm{WO}_{3}$ & 0.81 & 0.65 & 0.58 & 0.51 & 0.76 \\
\hline $\mathrm{Ta}_{2} \mathrm{O}_{5}$ & 4.51 & 3.81 & 4.09 & 5.82 & 4.83 \\
\hline $\mathrm{ZrO}_{2}$ & 0.64 & 0.34 & 0.18 & 0.05 & 0.34 \\
\hline $\mathrm{SiO}_{2}$ & 1.63 & 64.31 & - & - & - \\
\hline $\mathrm{Y}_{2} \mathrm{O}_{3}$ & 0.15 & 0.050 & 0.036 & 0.09 & 0.039 \\
\hline $\mathrm{Sc}_{2} \mathrm{O}_{3}$ & 0.135 & 0.066 & 0.134 & 0.133 & 0.075 \\
\hline
\end{tabular}

*Reported results from the London and Scandinavian Metallurgical Co Limited (LSM) Analytical Services

The incomplete sample dissolution and low recoveries obtained from the 1:10 sample to flux ratio compared to their expected content values in Table 1 prompted a further investigation to optimize the experimental conditions for the dissolution method of this mineral sample. The $\mathrm{Al}_{2} \mathrm{O}_{3}$ results were found to be highly inaccurate, possibly due the presence of residual fluoride from ammonium bifluoride. The $\mathrm{SiO}_{2}$ results were highly inaccurate and this could have been due to the formation of ammonium and were not included in subsequent analyses (Timokhin and Komarova, 1986).

\subsubsection{Influence of sample:flux ratio and the fusion time on Sample A}

Three portions of Sample A (approximately $0.05 \mathrm{~g}$ ) were weighed (accurately weighed to 0.1 $\mathrm{mg}$ ) in three different platinum crucibles. In the $1^{\text {st }}$ crucible, Sample A was mixed with $\mathrm{NH}_{4} \mathrm{~F} \cdot \mathrm{HF}$ flux in ratio of 1:20 sample:flux and fused for $30 \mathrm{~min}$ at $200{ }^{\circ} \mathrm{C}$. The $2^{\text {nd }}$ and the $3^{\text {rd }}$ portions were mixed with $\mathrm{NH}_{4} \mathrm{~F} \cdot \mathrm{HF}$ flux in ratio of 1:10 sample:flux and fused at $200{ }^{\circ} \mathrm{C}$ for 60 min and for $90 \mathrm{~min}$ respectively. The obtained melts were allowed to cool to ambient temperature and then dissolved in water and visual inspection indicated that small portions of the sample had not dissolved in the mixtures. The undissolved solids were removed by filtration and the solutions were quantitatively transferred to $100.0 \mathrm{~mL}$ volumetric flasks and filled to the mark with ultra- 
pure water. $10.0 \mathrm{~mL}$ aliquots of each solution were transferred to another $100.0 \mathrm{~mL}$ volumetric flask and $10 \mathrm{~mL} 95-97 \% \mathrm{H}_{2} \mathrm{SO}_{4}$ was added to each volumetric flask. The solutions were left to cool down and then filled to the mark with ultra-pure water for quantitative analysis using ICPOES. The obtained results are given in Table 2. Comparing the analytical results obtained in the above sections with those of the expected results, a 60 min digestion period at $200{ }^{\circ} \mathrm{C}$ with a $1: 10$ sample:flux ratio was selected as optimum experimental conditions for the rest of the investigation (comparing the \% content of the major elements such as $\mathrm{Nb}, \mathrm{Ta}$ and $\mathrm{Sc}$ ).

\subsubsection{Application of the optimal experimental conditions for the dissolution of Samples $A$ and $B$} The $\mathrm{NH}_{4} \mathrm{~F} \cdot \mathrm{HF}$ fusion and dissolution procedures were repeated for Sample A and Sample B. Approximately $0.05 \mathrm{~g}$ (accurately weighed to $0.1 \mathrm{mg}$ ) of each mineral sample was thoroughly mixed with $0.5 \mathrm{~g}$ of $\mathrm{NH}_{4} \mathrm{~F} \cdot \mathrm{HF}$ in platinum crucibles and fused at $200{ }^{\circ} \mathrm{C}$ for $60 \mathrm{~min}$. The obtained melts were cooled to room temperature and dissolved in water and visual inspection indicated that small amounts of the sample did not dissolve in the mixtures. After filtering, the filtrates were quantitatively transferred to $100.0 \mathrm{~mL}$ volumetric flasks and filled to the mark with ultra-pure water and allowed to stabilize for 4 hours. These were further diluted by pipetting 10.0 $\mathrm{mL}$ aliquot of each solution to $100.0 \mathrm{~mL}$ volumetric flasks, adding $10 \mathrm{~mL} 95-97 \% \mathrm{H}_{2} \mathrm{SO}_{4}$, and allowing the solutions to cool to room temperature before filling them to the mark with ultrapure water. The ICP-OES analyses of the two samples are reported in Table 3.

The analytical results in Table 3 indicated that $\mathrm{Fe}$ and $\mathrm{Ti}$ (most probably ilmenite) were the impurities with the highest concentration and it was decided to try and remove the two metals prior to dissolution to limit the amount and type of down-stream impurities. Magnetic separation was used to remove the magnetically susceptible properties prior to dissolution and solvent extraction separation. 
Table 3: Quantitative results obtained after the fusion dissolution of Samples A and B with $\mathrm{NH}_{4} \mathrm{~F} \cdot \mathrm{HF}$ (1:10 sample:flux ratio) at $200{ }^{\circ} \mathrm{C}$ for $60 \mathrm{~min}$

\begin{tabular}{|c|c|c|c|c|}
\hline \multirow{2}{*}{ Element } & \multicolumn{2}{|c|}{ Sample A } & \multicolumn{2}{c|}{ Sample B } \\
\cline { 2 - 5 } & Expected \% * & Experimental \%* & Expected \%* & Experimental \% \\
\hline $\mathrm{Nb}_{2} \mathrm{O}_{5}$ & 43.74 & 42.14 & 3.89 & 3.51 \\
\hline $\mathrm{Fe}_{2} \mathrm{O}_{3}$ & 29.49 & 28.86 & 39.93 & 34.02 \\
\hline $\mathrm{TiO}_{2}$ & 10.63 & 0.34 & 1.58 & 0.93 \\
\hline $\mathrm{Mn}_{3} \mathrm{O}_{4}$ & 2.10 & 1.74 & 0.26 & 0.29 \\
\hline $\mathrm{SnO}_{2}$ & 1.42 & 4.85 & 2.45 & 0.33 \\
\hline $\mathrm{U}_{3} \mathrm{O}_{8}$ & $<0.05$ & 0.002 & 0.19 & 0.00 \\
\hline $\mathrm{ThO}_{2}$ & $<0.055$ & 0.00 & 0.18 & 0.00 \\
\hline $\mathrm{WO}_{3}$ & 0.81 & 0.77 & 0.31 & 0.07 \\
\hline $\mathrm{Ta}_{2} \mathrm{O}_{5}$ & 4.51 & 4.61 & 0.35 & 0.53 \\
\hline $\mathrm{ZrO}_{2}$ & 0.64 & 0.06 & 1.38 & 0.17 \\
\hline $\mathrm{Y}_{2} \mathrm{O}_{3}$ & 0.15 & 0.09 & 0.38 & 0.03 \\
\hline $\mathrm{Sc}_{2} \mathrm{O}_{3}$ & 0.135 & 0.14 & 0.795 & 0.51 \\
\hline
\end{tabular}

*Reported results from the London and Scandinavian Metallurgical Co Limited (LSM) Analytical Services

\# Average of three replicates

\subsection{Magnetic removal of Fe and Ti in Samples A and B}

\subsubsection{Magnetic susceptibility determinations}

The magnetic susceptibility of Samples A and B were determined as follows: the MSB balance was reset to zero and the empty capillary tube was weighed and then placed into the balance to determine the $\mathrm{R}_{0}$ value. After this, the capillary tube was refilled with sample to a height between $2.6 \mathrm{~cm}$ and $3.1 \mathrm{~cm}$. The capillary tube with the sample was re-weighed and the $\mathrm{R}$ value was recorded. The mass susceptibility $\left(\chi_{\mathrm{g}}\right)$ of the samples was calculated as $1.301 \mathrm{x} 10^{-6}$ and 0.0713 $10^{-6} \mathrm{~cm}^{3} \cdot \mathrm{g}^{-1}$ for Samples A and B respectively.

\subsubsection{Magnetic removal of Fe and Ti from Samples $A$ and $B$}

The magnetic particles in $1.0 \mathrm{~g}$ portions of Samples A and B were repeatedly removed (using a permanent magnet) until visual inspection indicated that all the magnetic material was collected. The collected magnetic and non-magnetic portions were accurately weighed $(0.1 \mathrm{mg})$, quantitatively transferred to platinum crucibles and thoroughly mixed with $\mathrm{NH}_{4} \mathrm{~F} \cdot \mathrm{HF}$ in a $1: 10$ sample:flux ratio. The mixtures were fused at $200{ }^{\circ} \mathrm{C}$ for $60 \mathrm{~min}$ in the high temperature oven. The fusion melts were then cooled to ambient temperature and dissolved with ultra-pure water. 
Visual inspection indicated that some of the samples did not dissolve in the mixtures. The mixtures were filtered and the filtrate solutions were quantitatively transferred to $100.0 \mathrm{~mL}$ PTFE volumetric flasks and filled to the mark with ultra-pure water. A $10 \mathrm{~mL}$ aliquot of each solution was transferred to another $100.0 \mathrm{~mL}$ volumetric flask and the acidity of the solution adjusted with of $95-97 \% \mathrm{H}_{2} \mathrm{SO}_{4}$, cooled and then filled to the mark with ultra-pure water. The solutions were analysed using ICP-OES and the results are presented in Table 4. The impact of magnetic separation differences are better observed in the graphical presentations in Figures 2 and 3 for Sample A and B respectively. These results clearly indicated that the elements of interest were present in both the portions (magnetic and non-magnetic) and thus no additional benefit was obtained from such a separation. Despite this observation, it was also obvious that a larger concentration of the elements of interest occurred in the non-magnetic portion of samples $\mathrm{A}$ and $\mathrm{B}$, and hence the subsequent solvent extraction concentrated on the non-magnetic fraction of the samples.

Table 4: ICP-OES results for the elemental quantification of the magnetic and non-magnetic portions of Samples A and B

\begin{tabular}{|c|c|c|c|c|c|c|}
\hline \multirow{2}{*}{ Element } & \multicolumn{3}{|c|}{ Sample A (\%)* } & \multicolumn{3}{c|}{ Sample B (\%)* } \\
\hline & Expected & Magnetic & Non-magnetic & Expected & Magnetic & Non-magnetic \\
\hline $\mathrm{Nb}_{2} \mathrm{O}_{5}$ & 43.74 & 11.81 & 26.73 & 3.89 & 1.18 & 2.15 \\
\hline $\mathrm{Fe}_{2} \mathrm{O}_{3}$ & 29.49 & 9.32 & 17.58 & 39.93 & 11.32 & 20.63 \\
\hline $\mathrm{TiO}_{2}$ & 10.63 & 3.57 & 6.14 & 1.58 & 0.40 & 0.42 \\
\hline $\mathrm{Mn}_{3} \mathrm{O}_{4}$ & 2.10 & 0.51 & 0.99 & 0.26 & 0.20 & 0.10 \\
\hline $\mathrm{SnO}_{2}$ & 1.42 & 0.07 & 0.30 & 2.45 & 0.07 & 0.14 \\
\hline $\mathrm{U}_{3} \mathrm{O}_{8}$ & $<0.05$ & 0.00 & 0.00 & 0.19 & 0.00 & 0.00 \\
\hline $\mathrm{ThO}_{2}$ & $<0.055$ & 0.00 & 0.00 & 0.18 & 0.00 & 0.00 \\
\hline $\mathrm{WO}_{3}$ & 0.81 & 0.25 & 0.52 & 0.31 & 0.02 & 0.02 \\
\hline $\mathrm{Ta}_{2} \mathrm{O}_{5}$ & 4.51 & 1.35 & 2.99 & 0.35 & 0.22 & 0.23 \\
\hline $\mathrm{ZrO}_{2}$ & 0.64 & 0.02 & 0.03 & 1.38 & 0.01 & 0.13 \\
\hline $\mathrm{Y}_{2} \mathrm{O}_{3}$ & 0.15 & 0.02 & 0.03 & 0.38 & 0.02 & 0.01 \\
\hline $\mathrm{Sc}_{2} \mathrm{O}_{3}$ & 0.135 & 0.06 & 0.09 & 0.795 & 0.23 & 0.24 \\
\hline
\end{tabular}

* Average of two analyses 


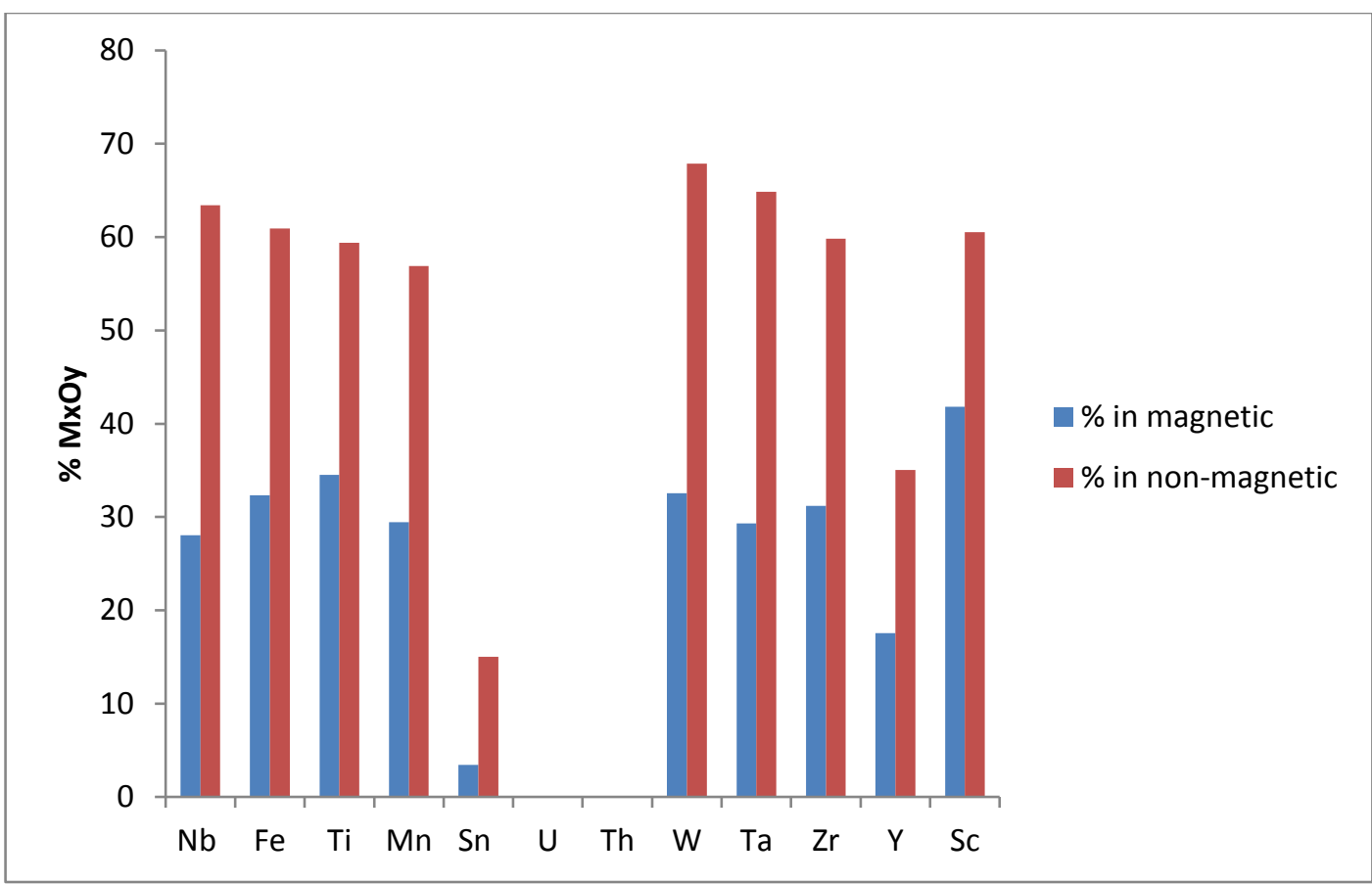

Figure 2: The \% analytes present in Sample A after magnetic separation

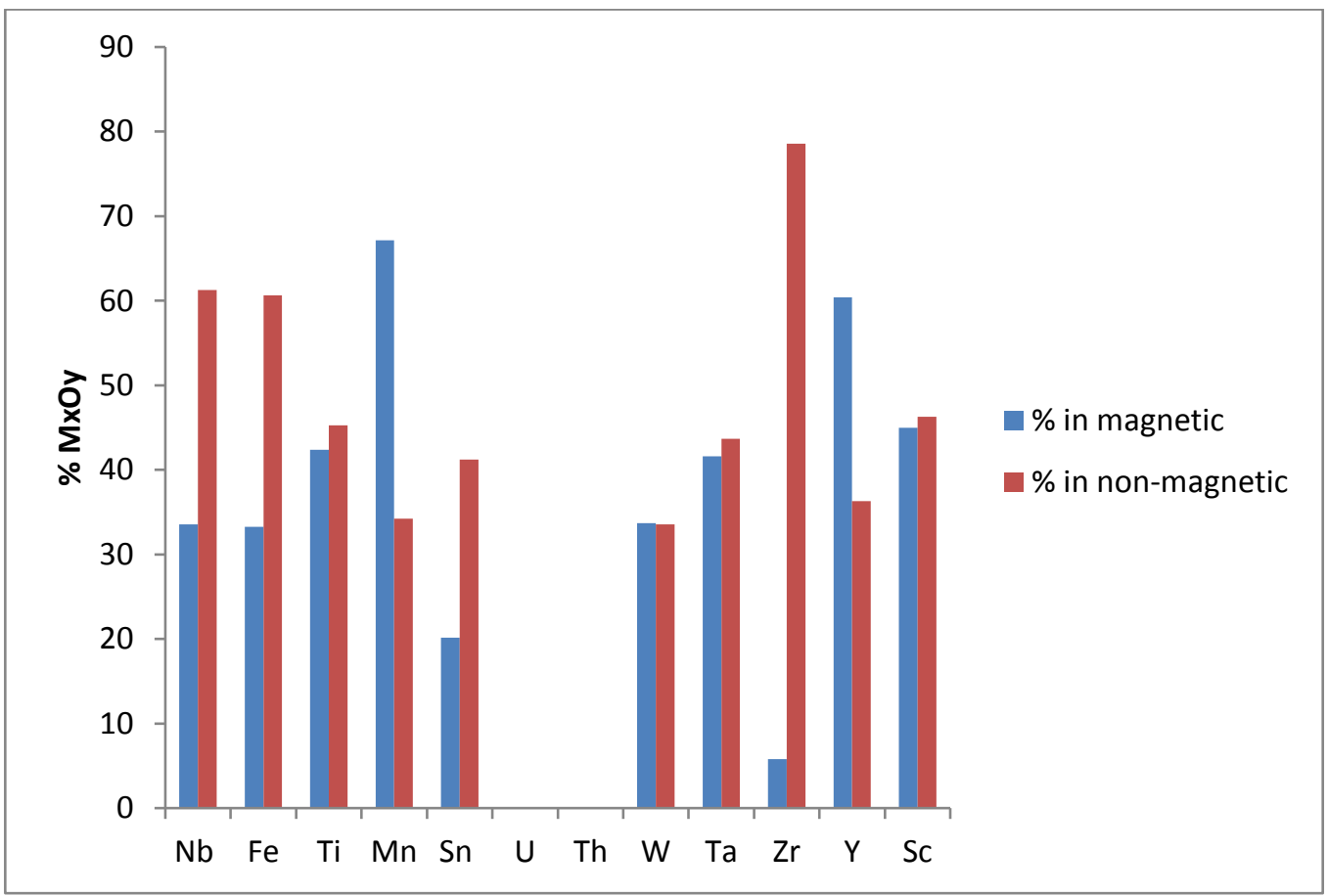

Figure 3: The $\%$ analytes present in Sample B after magnetic separation 


\subsection{Solvent extraction of tantalum from Sample A}

The next step in the process involved the removal of Ta as one of the major elements in the samples, from the rest of the sample solution using solvent extraction. $5.0 \mathrm{~mL}$ of the bulk solution of Sample A obtained from the initial sample dissolution process (magnetic and nonmagnetic portions) was transferred to a separating funnel and $5.0 \mathrm{~mL}$ of the desired $\mathrm{H}_{2} \mathrm{SO}_{4}$ concentration $(2.0 \mathrm{M}$ to $8.0 \mathrm{M})$ was added to the solution as indicated in the study by Nete et al (2014). The solution was thoroughly mixed for $5 \mathrm{~min}$ and the Ta was then extracted with two successive portions of $10.0 \mathrm{~mL}$ of MIBK. Each time the solution was allowed to stand for $5 \mathrm{~min}$ to allow for the complete separation of the two immiscible liquid phases. The aqueous solution (the bottom layer) was then collected in a $100 \mathrm{~mL}$ beaker. This aqueous solution was stirred on a hot plate set at $60{ }^{\circ} \mathrm{C}$ for $10 \mathrm{~min}$ to evaporate any dissolved organic solvent and transferred to $100.0 \mathrm{~mL}$ volumetric flasks. The two organic portions were combined and back extracted with two portions of $20 \mathrm{~mL}$ water. The solution was allowed to stand for $5 \mathrm{~min}$ for the complete separation of the liquid phases. The water layer was then collected in a $100.0 \mathrm{~mL}$ beaker. The water solutions were then combined and heated to evaporate any dissolved organic solvent and quantitatively transferred to a $100.0 \mathrm{~mL}$ volumetric flask. The acidity of the solutions was adjusted with $\mathrm{H}_{2} \mathrm{SO}_{4}$ to match the $1.848 \mathrm{M} \mathrm{H}_{2} \mathrm{SO}_{4}$ of the blank and of the standard solutions. The solutions were again allowed to cool to room temperature and the volumetric flasks were then filled to mark with ultra-pure water and subsequently analyzed using ICP-OES. The results obtained in this study are presented in Table $\mathbf{5}$ and the average percentages obtained are graphically presented in Figures $\mathbf{4}$ and $\mathbf{5}$. 
Table 5: Solvent extraction (2x) of Ta in Sample A using MIBK after $\mathrm{NH}_{4} \mathrm{~F} \cdot \mathrm{HF}$ fusion

\begin{tabular}{|c|c|c|c|c|c|c|c|}
\hline \multirow{2}{*}{ Element } & \multirow{2}{*}{$\begin{array}{c}\text { Expected } \\
(\mathbf{\%})\end{array}$} & \multicolumn{5}{|c|}{ Aqueous } & \multicolumn{3}{c|}{ Organic } \\
\cline { 3 - 8 } & & $\mathbf{2 . 0}$ & $\mathbf{4 . 0}$ & $\mathbf{8 . 0}$ & $\mathbf{2 . 0}$ & $\mathbf{4 . 0}$ & $\mathbf{8 . 0}$ \\
\hline $\mathrm{Nb}_{2} \mathrm{O}_{\mathbf{5}}$ & $\mathbf{4 3 . 7 4}$ & $\mathbf{4 0 . 3 8}$ & $\mathbf{4 1 . 6 2}$ & $\mathbf{3 8 . 2 9}$ & $\mathbf{2 . 3 8}$ & $\mathbf{2 . 8 2}$ & $\mathbf{2 . 2 3}$ \\
\hline $\mathrm{Fe}_{2} \mathrm{O}_{3}$ & 29.49 & 27.11 & 27.73 & 27.41 & 1.43 & 1.63 & 1.25 \\
\hline $\mathrm{TiO}_{2}$ & 10.63 & 10.93 & 11.06 & 10.65 & 0.43 & 0.52 & 0.38 \\
\hline $\mathrm{Mn}_{3} \mathrm{O}_{4}$ & 2.10 & 1.90 & 1.90 & 1.91 & 0.17 & 0.18 & 0.16 \\
\hline $\mathrm{SnO}_{2}$ & 1.42 & 0.52 & 0.49 & 0.49 & 0.13 & 0.06 & 0.13 \\
\hline $\mathrm{U}_{3} \mathrm{O}_{8}$ & $<0.05$ & 0.00 & 0.00 & 0.00 & 0.00 & 0.00 & 0.00 \\
\hline $\mathrm{ThO}_{2}$ & $<0.055$ & 0.00 & 0.00 & 0.00 & 0.01 & 0.00 & 0.00. \\
\hline $\mathrm{WO}_{3}$ & 0.81 & 1.13 & 1.10 & 1.01 & 0.16 & 0.09 & 0.08 \\
\hline $\mathrm{Ta}_{2} \mathrm{O}_{5}$ & $\mathbf{4 . 5 1}$ & $\mathbf{0 . 8 9}$ & $\mathbf{0 . 9 1}$ & $\mathbf{0 . 8 8}$ & 4.51 & $\mathbf{4 . 0 8}$ & $\mathbf{4 . 2 5}$ \\
\hline $\mathrm{ZrO}_{2}$ & 0.64 & 0.08 & 0.08 & 0.08 & 0.03 & 0.03 & 0.03 \\
\hline $\mathrm{Y}_{2} \mathrm{O}_{3}$ & 0.15 & 0.08 & 0.08 & 0.08 & 0.05 & 0.05 & 0.05 \\
\hline $\mathrm{Sc}_{2} \mathbf{O}_{3}$ & $\mathbf{0 . 1 3 5}$ & $\mathbf{0 . 1 5}$ & $\mathbf{0 . 1 5}$ & $\mathbf{0 . 1 5}$ & $\mathbf{0 . 0 0}$ & $\mathbf{0 . 0 0}$ & $\mathbf{0 . 0 0}$ \\
\hline
\end{tabular}

Bold $=$ Elements of interest

The results in Table 5 indicated that some of $\mathrm{Nb}$ was also extracted with Ta to organic phase. In the next part of the study the influence of increased $\left[\mathrm{H}_{2} \mathrm{SO}_{4}\right]$ on the extraction of $\mathrm{Nb}$ and $\mathrm{Sc}$ from the non-magnetic portion of Sample A into the organic phase was determined.

\subsubsection{Solvent extraction of non-magnetic portion of Sample A with MIBK}

Aliquots $(5.0 \mathrm{~mL})$ of the non-magnetic portion of Sample A obtained from Section 2.4.2 were transferred to a separating funnel and $5 \mathrm{~mL}$ of desired concentration $(4.0-16 \mathrm{M}) \mathrm{H}_{2} \mathrm{SO}_{4}$ solution was added to the solution. The solution was thoroughly mixed for $5 \mathrm{~min}$ and $\mathrm{Ta}$ and $\mathrm{Nb}$ were then extracted with two successive portions of $10.0 \mathrm{~mL}$ MIBK. The aqueous solution was collected in a $100 \mathrm{~mL}$ beaker and heated to remove any dissolved organic solvent then transferred to $100.0 \mathrm{~mL}$ volumetric flask. The organic phase was back extracted with two portions of $20 \mathrm{~mL}$ water and the water solutions were collected and combined in a $100 \mathrm{~mL}$ beaker and heated to remove any dissolved organic solvent. The aqueous portions were then quantitatively transferred to a $100.0 \mathrm{~mL}$ volumetric flask. The acidity of the solution was adjusted with $\mathrm{H}_{2} \mathrm{SO}_{4}$ to match the blank and the standard solution matrices. The solutions were then filled to the mark with ultra-pure water and subsequently analysed using ICP-OES. The results presented in Figure 4 shows the relationship between the acid concentration and the \% elemental extraction, especially $\mathrm{Ta}, \mathrm{Nb}$ and $\mathrm{Sc}$. 


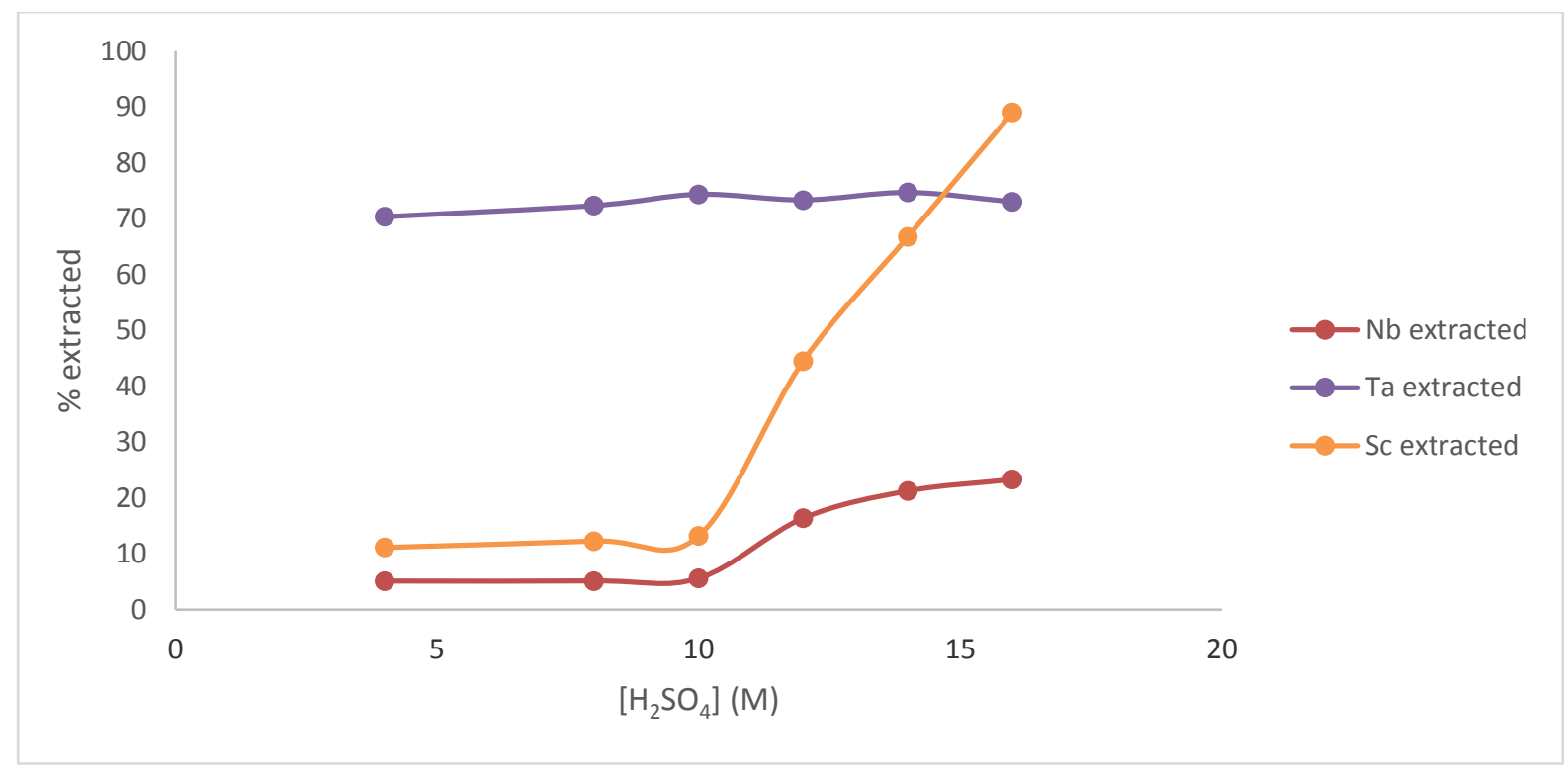

Figure 4: $\% \mathrm{Nb}$, Ta and $\mathrm{Sc}$ extracted with MIBK at different $\left[\mathrm{H}_{2} \mathrm{SO}_{4}\right]$

From the results in Figure 4 it can be seen that the MIBK solvent could be used for both collective and selective extraction of $\mathrm{Ta}$ and $\mathrm{Nb}$. However, the results indicated that as the acid concentration increased, Sc was also being extracted into the organic layer, which results in a substantial transfer of Sc from the aqueous layer. Once the initial separation of tantalum as well as the combination of niobium and scandium has been achieved through acid concentration variation below $10 \mathrm{M}$, a further separation of scandium and niobium can be accomplished with a further increase of $\left[\mathrm{H}_{2} \mathrm{SO}_{4}\right]$ to $16 \mathrm{M} \mathrm{H}_{2} \mathrm{SO}_{4}$. Even though this was one method to separate scandium from the rest of the elements, it was decided to extend the investigation to include other potential organic extractants.

Despite its success as extractant, MIBK had a number of disadvantages that included a low flash point $\left(14{ }^{\circ} \mathrm{C}\right)$ and relatively high solubility (1.91\%) in aqueous solutions, which necessitated its evaporating before ICP-OES analyses. Octan-1-ol and methyl isoamyl ketone (MIAK) each have a solubility of $1.0 \times 10^{-6}$ and $0.50 \%$ in water and respective flash points of 81 and $43{ }^{\circ} \mathrm{C}$ (Nete, 2013) and were also included as organic extractants in this study. 
2.5.2 Solvent extraction of tantalum and niobium in the non-magnetic portion of Sample A with octan-1-ol and MIAK

A $5.0 \mathrm{~mL}$ aliquot of the Sample A solution obtained in Section $\mathbf{2 . 4 . 2}$ was mixed with $5 \mathrm{~mL}$ of desired concentration $(4.0-16 \mathrm{M}) \mathrm{H}_{2} \mathrm{SO}_{4}$ solution in a separating funnel. Extraction of $\mathrm{Ta}$ and $\mathrm{Nb}$ was performed with two successive portions of $10.0 \mathrm{~mL}$ of each solvent and back extraction (from the organic phase) was done with two portions of $20 \mathrm{~mL}$ distilled water. All the aqueous solutions were heated to about $60{ }^{\circ} \mathrm{C}$ for $10 \mathrm{~min}$ in glass beakers to ensure that all the organic solvents were removed and then transferred to $100.0 \mathrm{~mL}$ volumetric flasks. The acidity of the solutions was adjusted to $1.8 \mathrm{M} \mathrm{H}_{2} \mathrm{SO}_{4}$ to match the blank and standard solutions. The solutions were allowed to cool to room temperature and then filled to the mark with ultra-pure water. The results in Table 6 dealing with octan-1-ol follow the same trend as observed in Figure 4 with MIBK as extractant. In contrast the results in Table 7 indicated no detectable Sc extraction into the organic layer at all.

Table 6: Elemental analysis of the aqueous portion of the non-magnetic portion of Sample A with octan-1-ol at $\left[\mathrm{H}_{2} \mathrm{SO}_{4}\right]$ between 4 and $16 \mathrm{M}$

\begin{tabular}{|c|c|c|c|c|c|c|c|c|c|c|c|c|c|}
\hline \multirow{3}{*}{ Element } & \multirow{3}{*}{$\begin{array}{c}\text { Expected } \\
\% *\end{array}$} & \multicolumn{12}{|c|}{$\left[\mathrm{H}_{2} \mathrm{SO}_{4}\right] / \mathrm{M}$} \\
\hline & & \multicolumn{2}{|c|}{4.0} & \multicolumn{2}{|c|}{8.0} & \multicolumn{2}{|c|}{10.0} & \multicolumn{2}{|c|}{12.0} & \multicolumn{2}{|c|}{14.0} & \multicolumn{2}{|c|}{16.0} \\
\hline & & Aq & Org & $\mathbf{A q}$ & Org & Aq & Org & $\mathbf{A q}$ & Org & Aq & Org & $\mathbf{A q}$ & Org \\
\hline $\mathrm{Nb}_{2} \mathrm{O}_{5}$ & 26.73 & 19.15 & 4.66 & 17.83 & 4.79 & 16.53 & 6.34 & 14.62 & 8.60 & 14.28 & 11.33 & 10.94 & 14.10 \\
\hline $\mathrm{Fe}_{2} \mathrm{O}_{3}$ & 17.58 & 17.85 & 0.43 & 16.53 & 0.00 & 16.86 & 0.86 & 15.58 & 0.60 & 15.27 & 0.57 & 15.31 & 0.56 \\
\hline $\mathrm{TiO}_{2}$ & 6.14 & 5.26 & 0.54 & 5.11 & 0.86 & 5.29 & 0.38 & 4.79 & 1.02 & 4.93 & 0.99 & 4.99 & 0.67 \\
\hline $\mathrm{Mn}_{3} \mathrm{O}_{4}$ & 0.99 & 1.05 & 0.13 & 1.24 & 0.12 & 1.10 & 0.20 & 1.25 & 0.35 & 1.29 & 0.36 & 1.28 & 0.20 \\
\hline $\mathrm{SnO}_{2}$ & 0.30 & 0.44 & 0.09 & 0.51 & 0.06 & 0.38 & 0.10 & 0.33 & 0.04 & 0.25 & 0.05 & 0.30 & 0.05 \\
\hline $\mathrm{U}_{3} \mathrm{O}_{8}$ & 0.00 & 0.31 & 0.03 & 0.30 & 0.05 & 0.29 & 0.03 & 0.09 & 0.01 & 0.23 & 0.00 & 0.20 & 0.01 \\
\hline $\mathrm{ThO}_{2}$ & 0.00 & 0.01 & 0.01 & 0.05 & 0.09 & 0.06 & 0.09 & 0.00 & 0.06 & 0.00 & 0.09 & 0.00 & 0.06 \\
\hline $\mathrm{WO}_{3}$ & 0.52 & 0.39 & 0.02 & 0.56 & 0.05 & 0.60 & 0.02 & 0.45 & 0.12 & 0.47 & 0.18 & 0.52 & 0.09 \\
\hline $\mathrm{Ta}_{2} \mathrm{O}_{5}$ & 2.99 & 0.86 & 2.12 & 0.85 & 2.08 & 0.89 & 2.09 & 0.45 & 2.28 & 0.59 & 2.23 & 0.61 & 2.22 \\
\hline $\mathrm{ZrO}_{2}$ & 0.03 & 0.10 & 0.00 & 0.12 & 0.00 & 0.09 & 0.00 & 0.06 & 0.03 & 0.07 & 0.00 & 0.09 & 0.05 \\
\hline $\mathrm{Y}_{2} \mathrm{O}_{3}$ & 0.03 & 0.04 & 0.02 & 0.06 & 0.02 & 0.04 & 0.03 & 0.04 & 0.03 & 0.04 & 0.05 & 0.03 & 0.05 \\
\hline $\mathrm{Sc}_{2} \mathrm{O}_{3}$ & 0.09 & 0.10 & 0.02 & 0.10 & 0.01 & 0.11 & 0.03 & 0.11 & 0.05 & 0.09 & 0.07 & 0.06 & 0.09 \\
\hline
\end{tabular}

* Elemental content present in non-magnetic portion of Sample A (Table 4)

Bold $=$ Elements of interest 
Table 7: Elemental analysis of the aqueous and organic portions of the non-magnetic portion of Sample A with MIAK at $\left[\mathrm{H}_{2} \mathrm{SO}_{4}\right]$ between 4 and $16 \mathrm{M}$

\begin{tabular}{|c|c|c|c|c|c|c|c|c|c|c|c|}
\hline \multirow{3}{*}{ Element } & \multirow{3}{*}{$\begin{array}{c}\text { Expected } \\
\% *\end{array}$} & \multicolumn{10}{|c|}{$\left[\mathrm{H}_{2} \mathrm{SO}_{4}\right] / \mathrm{M}$} \\
\hline & & \multicolumn{2}{|c|}{4.0} & \multicolumn{2}{|c|}{8.0} & \multicolumn{2}{|c|}{12.0} & \multicolumn{2}{|c|}{14.0} & \multicolumn{2}{|c|}{16.0} \\
\hline & & Aq & Org & Aq & Org & Aq & Org & Aq & Org & Aq & Org \\
\hline $\mathrm{Nb}_{2} \mathrm{O}_{5}$ & 26.73 & 21.42 & 0.88 & 20.12 & 0.91 & 20.56 & 0.57 & 25.26 & 0.28 & 20.36 & 0.74 \\
\hline $\mathrm{Fe}_{2} \mathrm{O}_{3}$ & 17.58 & 14.70 & 1.45 & 16.00 & 2.83 & 16.23 & 2.44 & 24.00 & 3.34 & 17.80 & 5.55 \\
\hline $\mathrm{TiO}_{2}$ & 6.14 & 6.07 & 0.88 & 6.51 & 0.88 & 5.53 & 0.77 & 6.73 & 0.71 & 6.29 & 0.81 \\
\hline $\mathrm{Mn}_{3} \mathrm{O}_{4}$ & 0.99 & 1.41 & 0.44 & 1.50 & 0.47 & 1.54 & 0.41 & 1.78 & 0.41 & 1.63 & 0.41 \\
\hline $\mathrm{SnO}_{2}$ & 0.30 & 0.31 & 0.12 & 0.40 & 0.17 & 0.33 & 0.14 & 0.61 & 0.55 & 0.38 & 0.27 \\
\hline $\mathrm{U}_{3} \mathrm{O}_{8}$ & 0.00 & 0.00 & 0.00 & 0.00 & 0.00 & 0.00 & 0.00 & 0.00 & 0.00 & 0.00 & 0.00 \\
\hline $\mathrm{ThO}_{2}$ & 0.00 & 0.00 & 0.00 & 0.00 & 0.00 & 0.00 & 0.00 & 0.00 & 0.00 & 0.00 & 0.00 \\
\hline $\mathrm{WO}_{3}$ & 0.52 & 0.34 & 0.08 & 0.25 & 0.19 & 0.44 & 0.26 & 0.89 & 0.42 & 0.25 & 0.05 \\
\hline $\mathbf{T a}_{2} \mathrm{O}_{5}$ & 2.99 & 1.11 & 3.12 & 0.83 & 3.32 & 0.83 & 2.77 & 0.68 & 3.25 & 0.19 & 2.56 \\
\hline $\mathrm{ZrO}_{2}$ & 0.03 & 0.11 & 0.02 & 0.11 & 0.02 & 0.12 & 0.02 & 0.15 & 0.02 & 0.12 & 0.01 \\
\hline $\mathrm{Y}_{2} \mathrm{O}_{3}$ & 0.03 & 0.01 & 0.00 & 0.01 & 0.00 & 0.01 & 0.00 & 0.02 & 0.00 & 0.00 & 0.00 \\
\hline $\mathrm{Sc}_{2} \mathrm{O}_{3}$ & 0.09 & 0.08 & 0.00 & 0.08 & 0.00 & 0.07 & 0.00 & 0.09 & 0.00 & 0.07 & 0.00 \\
\hline
\end{tabular}

* Elemental content present in non-magnetic portion of Sample A (Table 4)

Bold $=$ Elements of interest

Octan-1-ol behaved like MIBK solvent, and an increase in Nb extraction is observed when an increase in acidity. However, the increase in acidity also increased the Sc extraction and subsequent transfer from the aqueous layer. On the other hand, MIAK did not extract $\mathrm{Nb}$ or $\mathrm{Sc}$ even at high acid concentration levels. Results in Table 5 indicated that at least $2.23 \% \mathrm{Nb}_{2} \mathrm{O}_{5}$ was extracted at $8 \mathrm{M} \mathrm{H}_{2} \mathrm{SO}_{4}$ with MIBK. Since Sample B contained smaller amounts of $\mathrm{Nb}$ and Ta, MIBK was chosen for the removal of these two elements in Sample B.

\subsubsection{Solvent extraction of the elements in the non-magnetic portion of Sample B with MIBK}

A $5.0 \mathrm{~mL}$ aliquot of the bulk solution of Sample B non-magnetic portion obtained from Section 2.4.2 was transferred to a separating funnel and $5 \mathrm{~mL}$ of $8.0 \mathrm{M} \mathrm{H}_{2} \mathrm{SO}_{4}$ solution was added to this solution. The solution was thoroughly mixed for $5 \mathrm{~min}$ and the $\mathrm{Ta}$ and $\mathrm{Nb}$ was then extracted with two successive portions of $10.0 \mathrm{~mL}$ MIBK. The aqueous portion was collected in a $100 \mathrm{~mL}$ beaker, heated to remove any dissolved organic solvent and then transferred to $100.0 \mathrm{~mL}$ volumetric flask. The organic phase was back extracted with two portions of $20 \mathrm{~mL}$ water, the water portions were combined, heated to about $60{ }^{\circ} \mathrm{C}$ for $10 \mathrm{~min}$ in a glass beaker to ensure that 
all the organic solvents were removed and then quantitatively transferred to a $100.0 \mathrm{~mL}$ volumetric flask. The acidity of the solution was adjusted with $\mathrm{H}_{2} \mathrm{SO}_{4}$ to match the blank and the standard solutions matrices. The solutions were then filled to the mark with ultra-pure water and analysed using ICP-OES. The results are presented in Table 8. These results support those obtained in Sections 2.5.1 and 2.5.2 with both $\mathrm{Nb}$ and Ta being extracted into the organic layer and $\mathrm{Sc}$ remaining in the aqueous layer at $8 \mathrm{M}\left[\mathrm{H}_{2} \mathrm{SO}_{4}\right]$.

Table 8: Elemental analysis of the aqueous and organic portions of the non-magnetic portion of Sample B with MIBK at $\left[\mathrm{H}_{2} \mathrm{SO}_{4}\right]=8 \mathrm{M}$

\begin{tabular}{|c|c|c|c|}
\hline \multirow{2}{*}{ Element } & \multirow{2}{*}{ Expected \%* } & \multicolumn{2}{|c|}{$\left[\mathrm{H}_{2} \mathbf{S O}_{4}\right]=\mathbf{~ M}$} \\
\cline { 2 - 4 } & $\mathbf{2 . 1 5}$ & Aqueous & Organic \\
\hline $\mathrm{Nb}_{2} \mathbf{O}_{5}$ & 20.63 & $\mathbf{0 . 0 3}$ & $\mathbf{2 . 1 0}$ \\
\hline $\mathrm{Fe}_{2} \mathrm{O}_{3}$ & 0.42 & 18.16 & 2.95 \\
\hline $\mathrm{TiO}_{2}$ & 0.10 & 1.00 & 0.72 \\
\hline $\mathrm{Mn}_{3} \mathrm{O}_{4}$ & 0.14 & 0.58 & 0.48 \\
\hline $\mathrm{SnO}_{2}$ & 0.00 & 0.07 & 0.001 \\
\hline $\mathrm{U}_{3} \mathrm{O}_{8}$ & 0.00 & 0.00 & 0 \\
\hline $\mathrm{ThO}_{2}$ & 0.02 & 0.00 & 0 \\
\hline $\mathrm{WO}_{3}$ & $\mathbf{0 . 2 3}$ & 0.02 & 0.03 \\
\hline $\mathrm{Ta}_{2} \mathbf{O}_{5}$ & 0.13 & $\mathbf{0 . 0 3}$ & $\mathbf{0 . 2 1}$ \\
\hline $\mathrm{ZrO}_{2}$ & 0.01 & 0.02 & 0.01 \\
\hline $\mathrm{Y}_{2} \mathrm{O}_{3}$ & $\mathbf{0 . 2 4}$ & 0.00 & 0.00 \\
\hline $\mathrm{Sc}_{2} \mathbf{O}_{3}$ & $\mathbf{0 . 2 3}$ & $\mathbf{0 . 0 0}$ \\
\hline
\end{tabular}

* Elemental content present in non-magnetic portion of Sample B (Table 4)

Bold $=$ Elements of interest 


\section{Discussion of results}

\subsection{LOD, LOQ and elemental analysis of Samples A and B}

The limits of detection and the quantification were determined with the ICP-OES to determine the smallest concentrations of $\mathrm{Ta}, \mathrm{Nb}$ and $\mathrm{Sc}$ that could be reliably detected and quantified in the different samples. The LOD for Sc was determined to be 0.001085 at $361.384 \mathrm{~nm}$ in $\mathrm{H}_{2} \mathrm{SO}_{4}$ while the LOD's for Ta was calculated as 0.07768 at $228.916 \mathrm{~nm}$, and $\mathrm{Nb}$ as 0.01045 at 309.418 $\mathrm{nm}$ analytical lines, which indicated that the equipment and method was capable of detecting all three elements in the trace and ultra-trace concentration range. The LOQ's were calculated as 10x the LODs' values.

One of the major objectives of this study was to identify a dissolution method, which afforded the total dissolution of the ferrocolumbite mineral sample (Sample A) as well as the mine tailings (Sample B). The initial dissolution study performed on Sample A using $\mathrm{NH}_{4} \mathrm{~F} \cdot \mathrm{HF}$ as flux produced an easily soluble melt (water) fusion, but visual inspection indicated incomplete dissolution with the initial conditions used (1:10 sample:flux ratio at $200{ }^{\circ} \mathrm{C}$ for $\left.30 \mathrm{~min}\right)$. The analytical results obtained (Table 2) were compared to concentrations reported by the London and Scandinavian Metallurgical Co Limited (LSM) Analytical Services to evaluate the extent of dissolution. About $83 \%$ of the $\mathrm{Nb}_{2} \mathrm{O}_{5}, 89 \%$ of the $\mathrm{Fe}_{2} \mathrm{O}_{3}$ and $91 \%$ of the $\mathrm{TiO}_{2}$ (dominating elements in the sample) were recovered. Only about $49 \%$ of the $\mathrm{Sc}_{2} \mathrm{O}_{3}$ was recovered.

It was decided to investigate various experimental parameters such as sample to flux ratio and the fusion time to optimize the digestion method to effect complete dissolution and total elemental recovery. Both the increase in sample to flux ratio and duration of flux procedure improved elemental recovery, but the 1:10 sample to flux ratio and flux period of 60 min proved to an excellent experimental condition as illustrated by elemental recoveries of $96.30 \% \mathrm{Nb}_{2} \mathrm{O}_{5}$, $99.12 \% \mathrm{Fe}_{2} \mathrm{O}_{3}$ and $99.26 \% \mathrm{Sc}_{2} \mathrm{O}_{3}$.

The dissolution of both the samples was then repeated using the optimum condition and the results are reported in Table 3. Recoveries of 96(3) \% $\mathrm{Nb}_{2} \mathrm{O}_{5}, 97.9(9) \% \mathrm{Fe}_{2} \mathrm{O}_{3}, 97.3(2) \% \mathrm{TiO}_{2}$, 103.70(1) \% $\mathrm{Sc}_{2} \mathrm{O}_{3}$ and 102.2(2) \% $\mathrm{Ta}_{2} \mathrm{O}_{5}$ were obtained for Sample A, while 90.23(6) \% $\mathrm{Nb}_{2} \mathrm{O}_{5}$, 85(2) $\% \mathrm{Fe}_{2} \mathrm{O}_{3}$ and 64.15(2) \% $\mathrm{Sc}_{2} \mathrm{O}_{3}$ were recovered for Sample B. The good recoveries obtained for the main elements in Samples A and B were regarded as sufficient to continue with the rest of the solvent extraction study. The chemical analyses (Table 3) of two samples indicated that about $90 \%$ of the $\mathrm{Nb}_{2} \mathrm{O}_{5}, \mathrm{Ta}_{2} \mathrm{O}_{5}, \mathrm{TiO}_{2}$ and $\mathrm{Mn}_{3} \mathrm{O}_{4}$ were removed from the original columbite ore. The remaining elements present in the tailings were $\mathrm{Fe}_{2} \mathrm{O}_{3}(39.03 \%)$ as major impurity, $\mathrm{Al}_{2} \mathrm{O}_{3}(4.91 \%), \mathrm{Nb}_{2} \mathrm{O}_{5}(3.89 \%)$ and smaller amounts of $\mathrm{ZrO}_{2}(1.38 \%), \mathrm{Ta}_{2} \mathrm{O}_{5}(0.35$ $\%), \mathrm{TiO}_{2}(1.58 \%)$ and notably $\mathrm{Sc}_{2} \mathrm{O}_{3}(0.795 \%)$. These results suggested that the original extraction or beneficiation process did not remove any Sc from the mineral and that the Sc content was concentrated from 0.135 to $0.795 \%$. 


\subsection{Magnetic removal of major impurities from samples}

The chemical analysis of both Samples A and B clearly identified $\mathrm{Fe}\left(\mathrm{Fe}_{2} \mathrm{O}_{3}\right)$ as the major contaminant. The magnetic removal of iron from both samples should have reduced the amount of down-stream impurities and simplify any beneficiation process. The first step was to separate the magnetic and non-magnetic portions of both the samples and dissolve them with $\mathrm{NH}_{4} \mathrm{~F} \cdot \mathrm{HF}$ as flux to evaluate of the extent of Fe removal (as well as the other elements of interest) from both samples during the magnetic separation step.

From the elemental composition of the samples (A and B) in Table 3, it was expected that Sample B would be magnetically more active with large amounts of Fe present in the sample compared to Sample A. Initially the magnetism in the samples was quantitatively determined as mass magnetic susceptibility $\left(\chi_{\mathrm{g}}\right)$. The results indicated that Sample A contained much more magnetic particles $\left(1.301 \times 10^{-6} \mathrm{~cm}^{3} \mathrm{~g}^{-1}\right)$ than Sample B $\left(0.071310^{-6} \mathrm{~cm}^{3} \mathrm{~g}^{-1)}\right.$. These results were surprising since the Fe content increased from $28.86 \%$ in Sample A to about $40 \%$ in Sample B and yet its magnetic susceptibility decreased by a factor 100. In practice it implied that the chemical treatment of the original columbite mineral also changed the type of $\mathrm{Fe}$ compound in the final tailings, which rendered it less ferromagnetic (possible change in oxidation state). This was underlined by the quantitative results in Table 4, which indicated that poor separation or removal of Fe took place during the magnetic field exposure for both samples with a 50/50 separation between the magnetic and non-magnetic portion. The magnetic susceptibility in this columbite sample and its mine tailings samples was much lower than the values obtained for tantalite samples investigated by Nete (2012). The two tantalite samples had magnetic susceptibility values of 2.8 and $29.3 \times 10^{-6} \mathrm{~cm}^{3} \mathrm{~g}^{-1}$ compared to the $1.3 \times 10^{-6} \mathrm{~cm}^{3} \mathrm{~g}^{-1}$ of the original columbite ore sample. In that study the magnetic separation of the Fe from the rest of the elements was successfully applied to the tantalite samples with the high susceptibility values, while poor separation was also obtained for the tantalite sample with low susceptibility values. The experimental results (Table 4) for the magnetic separation in this study not only indicated the unsuccessful removal of the majority of $\mathrm{Fe}$ from the samples, but also indicated a substantial loss of $\mathrm{Sc}\left(40.00 \%\right.$ of $\mathrm{Sc}_{2} \mathrm{O}_{3}$ in Sample A was lost and $\left.45.01 \% \mathrm{Sc}_{2} \mathrm{O}_{3}\right)$.

\subsection{Solvent extraction of elements with MIBK as extractant}

Due to the incomplete magnetic removal of $\mathrm{Fe}$ and $\mathrm{Ti}$ from both samples, the subsequent solvent extraction separation was performed on the non-magnetic fraction of the samples. In this step, the efficiency of using MIBK as solvent for extracting the different elements was evaluated and the chemical behavior of ferrocolumbite with tantalite as natural mineral source was compared. The first step was to investigate the solvent extraction process using the complete Sample A. 


\subsubsection{Solvent extraction of elements in a Sample A with MIBK as extractant}

The efficiency of MIBK as solvent extractant was evaluated on Sample A $\left(\mathrm{NH}_{4} \mathrm{~F} \cdot \mathrm{HF}\right.$ dissolved) at different $\mathrm{H}_{2} \mathrm{SO}_{4}$ concentrations, ranging from $2.0 \mathrm{M}$ to $8.0 \mathrm{M}$. The results indicated that the double extraction process (Table 5) removed $92.84 \% \mathrm{Ta}$ and $4.88 \% \mathrm{Nb}$ and $4.99 \% \mathrm{Fe}$ from the aqueous layer into the organic layer. The results also indicated that the majority of $\mathrm{Sc}(\sim 100 \%)$ remained in the aqueous solution at this acid concentration, which implied a possible beneficiation of Sc. Poor extraction of the other elements also confirmed the possible isolation of Ta compound from the columbite matrix. At acid concentrations between 8 and $10 \mathrm{M}$ (see Figure 4) the extraction mechanism started to change, especially for Sc, which transferred from the aqueous to the organic layer with substantial amounts of Sc extracted at $\left[\mathrm{H}_{2} \mathrm{SO}_{4}\right]$ around 16 M.

The extent of extraction of each of the elements in the columbite sample by MIBK solvent at 8 $\mathrm{M} \mathrm{H}_{2} \mathrm{SO}_{4}$ is reflected by the calculated extraction ratios (D) and is presented in Table 9. Important to note is that extraction ratio (D) calculated for Ta greatly exceeded that of all other elements in solution.

Table 9: Distribution ratios for elements present in columbite sample after $\mathrm{x} 2$ extraction process with MIBK solvent at $8.0 \mathrm{M} \mathrm{H}_{2} \mathrm{SO}_{4}$

\begin{tabular}{|c|c|}
\hline Metal & Extraction ratio (D) \\
\hline $\mathrm{Nb}$ & 0.058 \\
\hline $\mathrm{Fe}$ & 0.046 \\
\hline $\mathrm{Ti}$ & 0.036 \\
\hline $\mathrm{Mn}$ & 0.084 \\
\hline $\mathrm{Sn}$ & 0.272 \\
\hline $\mathrm{U}$ & - \\
\hline $\mathrm{Th}$ & - \\
\hline $\mathrm{W}$ & 0.075 \\
\hline $\mathrm{Ta}$ & $\mathbf{4 . 8 0 8}$ \\
\hline $\mathrm{Zr}$ & 0.395 \\
\hline $\mathrm{Y}$ & 0.605 \\
\hline $\mathrm{Sc}$ & 0.000 \\
\hline
\end{tabular}

\subsubsection{Solvent extraction of the non-magnetic portion of Sample A with different organic} extractions

From Section 2.5.3 it was clear that Ta could be selectively removed and isolated from the columbite sample by solvent extraction technique using MIBK at $\mathrm{H}_{2} \mathrm{SO}_{4} \sim 8 \mathrm{M}$. The results 
obtained from octan-1-ol and MIAK indicated that octan-1-ol behaved like MIBK, at low $\left[\mathrm{H}_{2} \mathrm{SO}_{4}\right]$ and only Ta was extracted into the organic phase. At high $\left[\mathrm{H}_{2} \mathrm{SO}_{4}\right] \mathrm{Nb}$ was also extracted with Ta into the organic layer. About $52.75 \%$ Nb (Table 6) was extracted with octan$1-\mathrm{ol}$ at $\left[\mathrm{H}_{2} \mathrm{SO}_{4}\right]$ of $16 \mathrm{M}$ while $53.33 \%$ of Sc was also extracted. On the other hand, MIAK only extracted Ta selectively even at high acid concentrations. An average of $100.4 \%$ Ta was extracted with MIAK and only $2.77 \% \mathrm{Nb}$ was extracted at $16 \mathrm{M} \mathrm{H}_{2} \mathrm{SO}_{4}$ (Table 7). There was no notable amount of Sc that was extracted into the MIAK organic solvent.

\subsubsection{Solvent extraction of Ta and Nb in non-magnetic portion of Sample B with MIBK}

The results in Table 8 clearly indicated that $\mathrm{Ta}$ and $\mathrm{Nb}$ was successfully extracted with MIBK from a $\mathrm{NH}_{4} \mathrm{~F} \cdot \mathrm{HF}$ solution present in Sample B (non-magnetic) with $\left.8 \mathrm{M}^{2} \mathrm{H}_{2} \mathrm{SO}_{4}\right]$. An average of 97.67\% $\mathrm{Nb}$ and $91.30 \%$ Ta were extracted while 95.86 \% Sc was recovered from the aqueous solution. It is clear from the metal quantification of the mine or process tailings (Table 3) that it contained substantial amounts of the target elements, which could be separated and beneficiated with this extraction process. Although both $\mathrm{Ta}$ and $\mathrm{Nb}$ were present in the MIBK at $8 \mathrm{M}$ $\left[\mathrm{H}_{2} \mathrm{SO}_{4}\right]$, research results in this and in a previous study indicated the clean separation of the two elements using MIAK as extractant (Nete et al., 2014), which can be used for processing tailings.

\subsubsection{Summary of results}

The degree to which the process was successful in separating the elements of interest is summarised in Table 10. The extraction results (co-extraction of $\mathrm{Ta}$ and $\mathrm{Nb}$ in high acidity aqueous solutions) and the clean separation of the two elements with MIAK at high acidity support the results reported in two previous studies (Nete et al., 2014). Based on some of the results in Table 10, a possible process flow diagram for the separation of the three target elements is proposed in Figure 5.

Table 10: Evaluation of various steps involved in the separation processes investigated (Sample A) in this study

\begin{tabular}{|c|c|c|c|c|}
\hline \multirow[t]{2}{*}{ Process } & \multirow[t]{2}{*}{ Description } & \multicolumn{3}{|c|}{ Elemental Recovery (\%) } \\
\hline & & Ta & $\mathbf{N b}$ & Sc \\
\hline $\begin{array}{c}\text { Dissolution of the mineral } \\
\text { samples by } \mathrm{NH}_{4} \mathrm{~F} \cdot \mathrm{HF}\end{array}$ & $\begin{array}{l}\text { Complete dissolution } \\
\text { of ore/tailings }\end{array}$ & 99 & 96 & 99 \\
\hline \multirow{2}{*}{$\begin{array}{l}\text { Magnetic separation } \\
\text { (removal of } \mathrm{Fe} \text { and/or Ti) }\end{array}$} & Magnetic & 30 & 27 & 44 \\
\hline & Non-magnetic & 66 & 61 & 66 \\
\hline \multirow{2}{*}{$\begin{array}{l}\text { Solvent extraction with } \\
\text { MIBK }\left(8 \mathrm{M}\left[\mathrm{H}_{2} \mathrm{SO}_{4}\right]\right)\end{array}$} & Organic phase & 94 & 5 & 0 \\
\hline & Aqueous phase & 19 & 88 & 100 \\
\hline \multirow{2}{*}{$\begin{array}{l}\text { Solvent extraction with } \\
\text { MIBK }\left(16 \mathrm{M}\left[\mathrm{H}_{2} \mathrm{SO}_{4}\right]\right)\end{array}$} & Organic phase & 73 & 23 & 89 \\
\hline & Aqueous phase & 24 & 57 & 20 \\
\hline
\end{tabular}


Figure 5: Process flow diagram for the separation of $\mathrm{Ta}, \mathrm{Nb}$ and $\mathrm{Sc}$ in ferrocolumbite

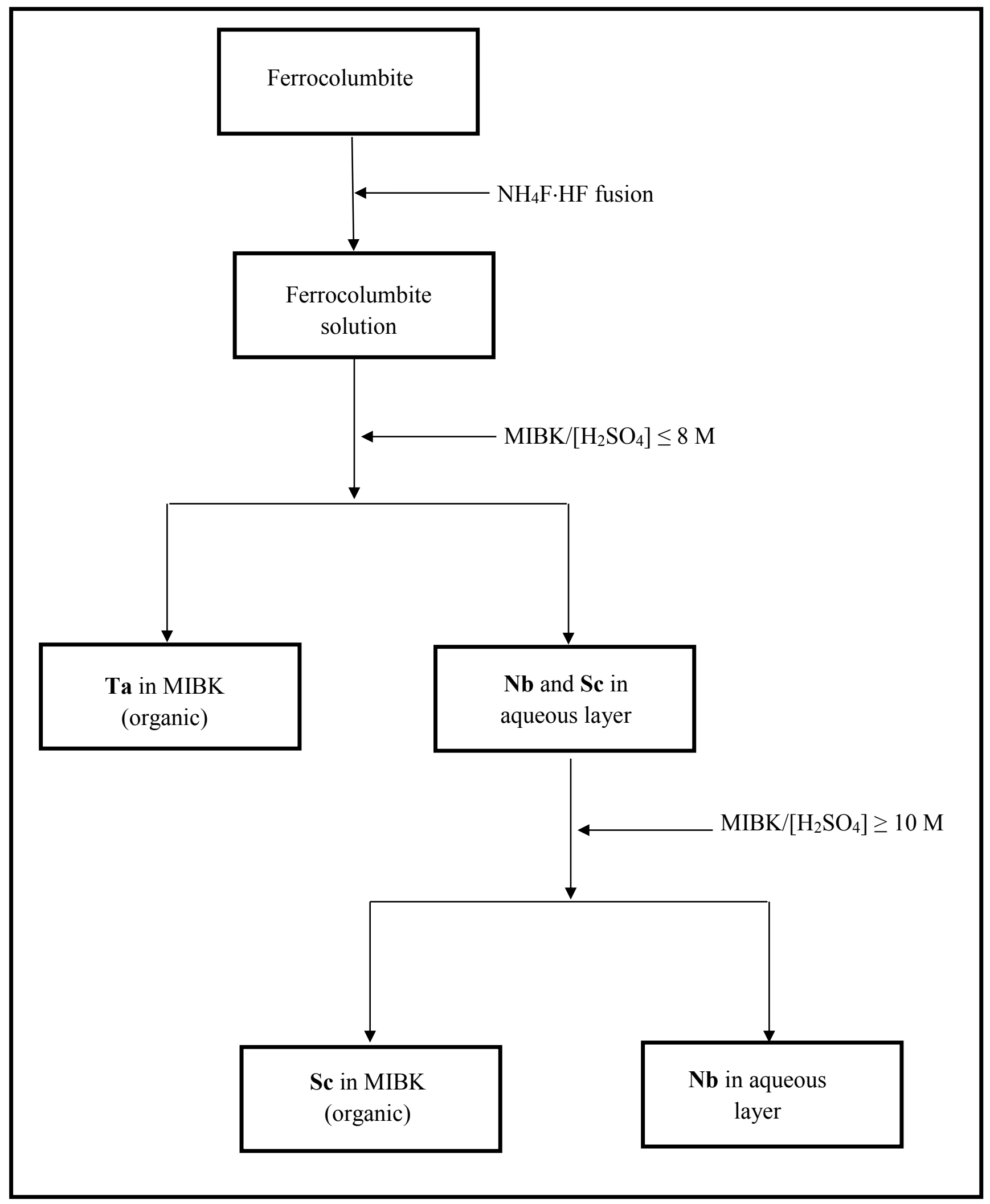




\section{Conclusion}

The following conclusions can be drawn from this investigation:

- Ferrocolumbite was successfully dissolved with $\mathrm{NH}_{4} \mathrm{~F}$. HF yielding a solution in which all three elements of interest were accurately quantified with satisfactory LOD/LOQ's

- Magnetic separation did not contribute to the successful removal of Fe/Ti to simplify the down-stream beneficiation processes

- MIBK successfully extracted Ta into the organic layer and left $\mathrm{Nb}$ and $\mathrm{Sc}$ in the aqueous layer at $\left[\mathrm{H}_{2} \mathrm{SO}_{4}\right]<8 \mathrm{M}$. At higher acid levels, Sc $\left(\left[\mathrm{H}_{2} \mathrm{SO}_{4}\right]>10 \mathrm{M}\right)$ migrated in significant amounts/quantities to the organic layer. This creates a possible process for the separation of the three elements from one another

- Octan-1-ol yielded similar results to MIBK while MIAK successfully removed Ta from the aqueous layer, but left the two other elements in the aqueous layer, even at $16 \mathrm{M}$ $\left[\mathrm{H}_{2} \mathrm{SO}_{4}\right]$

- Extraction process can successfully be applied to $\mathrm{Ta}, \mathrm{Nb}$ and $\mathrm{Sc}$ recovery in mine/process tailings

- A process flow sheet for the possible separation of $\mathrm{Nb}$, Ta and $\mathrm{Sc}$ from ferrocolumbite is proposed 


\section{References:}

Beurlen, H., da Silva, M.R.R., Thomas, R., Soares, D.R. \& Olivier, P., (2008), Nb-Ta-(Ti-Sn) oxide mineral chemistry as tracer of rare-element granitic pegmatite fractionation in the Borborema Province, Northeastern Brazil, Miner. Deposita 43, 207-228.

Burke, E. A. J., and Leake, B. E., (2008), Tidying up Mineral Names: an IMA-CNMNC Scheme for Suffixes, Hyphens and Diacritical marks, The Mineralogical Record, 39, 131-135.

Eckert, J., and Hermann, C., (1996), Ullmann's Encyclopedia of Industrial Chemistry, Niobium and Niobium Compounds, A17, VCH Verlagsgesellschaft, Weinheim, pp. 251-264.

Hayes, K. and Burge, R., (2003), "Coltan Mining in the Democratic Republic of Congo: How tantalum using industries can commit to the reconstruction of the DRC”, Fauna \& Flora International, Cambridge, UK.

Kempe, U. and Wolf, D., (2006), Anomalously high Sc contents in ore minerals from Sn-W deposits: possible economic significance and genetic implications, Ore Geol. Rev. 28, 103-122.

Krebs, R. E., (2006), The history and use of our earth's chemical elements: a reference guide, $2^{\text {nd }}$ ed. pp. 87-90, Greenwood Press, ISBN: 0-313-33438-2.

Lee, R., 10 Oct 2011, Assessing the Dodd-Frank Act, available from: http://www.osisa.org/general/drc/assessing-dodd-frank-act

Matsuno, H, Yokoyama, A, Watari, F, Uo, M, Kawasaki, T., (2001), Biocompatibility and osteogenesis of refractory metal implants, titanium, hafnium, niobium, tantalum and rhenium, Biomaterials 22, 1253-1262.

Nete, M., Purcell, W., Snyders, E., Nel, J.T., Beukes, G., (2012), Characterization and alternative dissolution of tantalite mineral samples from Mozambique. J. S. Afr. Inst. Min. Metall. 112, 1079-1086.

Nete, M., Purcell, W., Nel, J.T., Evaluation of ammonium bifluoride dissolution on different tantalum and niobium mineral samples, Proceedings of the 2013 conference of Advanced Metals Initiative. Precious Metals 2013, Cape Town, 14-16 October 2013, pp 21-26, The Southern African Institute of Mining and Metallurgy.

Nete M., (2013), Separation and purification of niobium and tantalum from synthetic and natural compounds, PhD. Thesis, Bloemfontein: University of the Free State, p. 191 
Nete, M., Purcell, W., Nel, J.T., (2014), Separation and isolation of tantalum and niobium from tantalite using solvent extraction and ion exchange. Hydrometallurgy 149, 31-40.

Pohl, W., (2011), Economic Geology Principles and Practice Metals, Minerals, Coal and Hydrocarbons - Introduction to Formation and Sustainable Exploitation of Mineral Deposits, p. 261, Blackwell Publishing Ltd. ISBN 978-1-4443-3662-7.

Ruiz, M.D.C., Rodriguez, M.H., Perino E., Olsina, R.A., (2002), Determination of Nb, Ta, Fe and Mn by X-Ray Fluorescence, Miner. Eng., 15, 373-375.

Timokhin, A. R. and Komarova, L. A., (1986), Chemical reaction of ammonium bifluoride with quartz glass, pp. 267-269, [Accessed 24-10-2015]. Available from: http://download.springer.com/static/pdf/837/art\%253A10.1007\%252FBF00697937.pdf?a uth66=1353397748_24e33c0ab6ff5c533fd24ef3dd809d02\&ext $=. p d f$

Wolfe, L., 2 Feb (2015), How Dodd-Frank is failing Congo, available from: http://foreignpolicy.com/2015/02/02/how-dodd-frank-is-failing-congo-mining-conflict$\underline{\text { minerals/ }}$

U.S. Geological Survey, (2015), Mineral commodity summaries 2015: U.S. Geological Survey, 196 p., http://dx.doi.org/10.3133/70140094. ISBN 978-1-4113-3877-7. 